\title{
Effect of initial pH on microenvironmental biomineralization of nitrate reducing bacteria
}

\author{
NA JIANG ${ }^{1,2}$, YUAN GUO $^{1}$, ZENGPING NING $^{1}$, LIKAI \\ $\mathrm{HAO}^{1,3}$ \\ ${ }^{1}$ State Key Laboratory of Environmental Geochemistry, \\ Institute of Geochemistry, Chinese Academy of Sciences, \\ Guiyang, China \\ jiangna@mail.gyig.ac.cn \\ ${ }^{2}$ University of Chinese Academy of Sciences, Beijing, China \\ haolikai@mail.gyig.ac.cn \\ ${ }^{3}$ CAS Center for Excellence in Quaternary Science and \\ Global Change, Xi'an, China
}

Microorganisms play an important role in the biogeochemical cycle of iron, and act as the fundamental driving force of elements geochemistry. The nitrate-reducing bacterium BoFeN1 coupling carbon cycling with iron oxidation, controls the transformation and (im)mobilization of heavy metals by oxidation, reduction and chelation ${ }^{[1]}$. It was found that lower $\mathrm{pH}$ microenvironment around phototrophic $\mathrm{Fe}(\mathrm{II})$-oxidizing bacteria prevent cell encrustation by $\mathrm{Fe}(\mathrm{III})$ minerals ${ }^{[2]}$. But the effect of initial $\mathrm{pH}$ on microenvironment of nitrate reducing bacteria BoFeN1 encrusting with $\mathrm{Fe}(\mathrm{III})$ precipitates is still unknowm.

This study aimed to reveal the effect of initial $\mathrm{pH}$ on microenvironment of microbial mineral precipitation. It was found that lower initial medium $\mathrm{pH}$ slowed the bacteria growth by prolonging the lag phase, decreasing the biomass, and finally influencing the crystallization degree of $\mathrm{Fe}(\mathrm{III})$ precipitates. Optical density, XRD, FTIR and TEM results confirmed that the more biomass and higher crystallization degree of mineralized products with the higher initial medium $\mathrm{pH}$. These findings will better our understanding of the microenvironment gradients for cell iron minerals encrustation and the microscale mechanism controling the microbial biomineralization. Moreover, we've done the sample preparation for FIB/SEM tomography presently, and the next step is to realize 3-D analysis of mineralized products at different initial medium $\mathrm{pH}$.

[1] Kappler, A.; Straub, K. L. Molecular Geomicrobiology 2005, 59, 85.

[2] Hegler, F.; Schmidt, C.; Schwarz, H.; Kappler, A. FEMS Microbiology Ecology 2010, 74, 592. 